\title{
РАЗЛИЧИЯ И НЕРАВЕНСТВА В ЗДРАВЕТО ПРИ ЛИЦАТА С РАЗЛИЧНА СТЕПЕН НА УВРЕЖДАНИЯ \\ Б. Ивков
}

\section{DIFFERENCES AND HEALTH INEQUALITIES IN PERSONS WITH VARIOUS DEGREE OF DISABILITY}

\author{
B. Ivkov
}

Рез юме. Един от най-актуалните и болезнени проблеми на сочиалната политика в България в настоящия момент е този за статута на хората с увреждания, начините на неговата легитимачия и очакваните от обществото промени в тази област. За да бъдат обаче тези политики адекватни и за да отговарят на очакванията на обществените настроения, е необходима релевантна информация, придобита по пътя както на официалната статистика, така и посредством иеленасочени емпирични изследвания. В статията се обсъждат резултатите от проведено през 2017 г. изследване на соииалните неравенства в здравето ${ }^{1}$. Анализирани и оиенени са различията и неравенствата между отделните субкатегории лииа с увреждания. Подчертава се, че разглеждането им като хомогенна социална група прикрива спецификата и потребностите на всяка от тези субкатегории. В същото време подобен подход затруднява разработването на индивидуално ориентирани сочиални политики, съобразени с възможностите и потребностите на отделния човек.

S u $\mathbf{m} \mathbf{m}$ a ry. One of the most topical and painful social policy issues in Bulgaria today is the status of people with disabilities, the paths to its legitimization, and the changes that society expects to see in this regard. To design policies that respond to societal expectations, more information is needed, acquired both from existing statistical data and from targeted empirical studies. This article discusses the results from a 2017 survey of health inequality. We analyze and evaluate the differences and inequalities between subcategories of people with disabilities. We underscore that looking at this group of people as a whole masks the specific needs of each subcategory. What's more, such a one-size-fits-all approach makes it difficult to develop individually tailored social policies in line with the abilities and needs of different people.

Key words: people with disabilities, health inequality, social policy, health, health problems

$\Pi$

рез последните десетилетия непрестанно се увеличава значимостта на проблемите, свързани с различията и неравенствата сред хората с увреждания както в национален, така и в глобален мащаб. Причините могат да се търсят както в стареенето на населението, така и в неадекватните социални политики и отлагане във времето на тяхното адаптиране и внедряване в социалната практика. Не бива да се пропуска и фактьт, че към хората с увреждания се подхожда като към една еднородна група, без да се отчитат спецификите на всяко от уврежданията, техните етапи на развитие и социалните им измерения. Това е и една от причините за изследване на специфичните особености на социалната структура и социалните неравенства вътре в социалната категория „хора с увреждания“.

Цел на изследването е анализ и оценка на неравенствата в здравето между четирите социални субкатегории: лица с под 50\% трайно намалена работоспособност (тр.н.р.), с над 50\% до 70\% тр.н.р., с над 70\% до 90\% тр.н.р., с над $90 \%$ тр.н.р.

Обект на изследване е пълнолетното население на страната, притежаващо социалния правен статус „лице с увреждане“. При формирането на извадката е използван моделът на двустепенната гнездова извадка. Тя е проектирана и реализирана като национална представителна за населението в страната. Броят на лицата в нея е 2340 лица, избрани от 180 гнезда. Поради малкия брой лица с увреждания в националната извадка е използвана и допълваща извадка, включваща 12 гнезда. При този подход общият брой на лицата с различна степен на увреждане е 478 лица.

\section{Методи}

Регистрацията на информацията при изследването е изпълнена съгласно изискванията на метода интервю ,лице в лице“ със специално разработен за целта въпросник.

\section{Резултати}

Общият брой на лицата с различна степен на увреждане е 478. Вътрешната структура според степента на увреждане и тр.н.p. е следната: до 50\% тр.н.p. $-5.4 \%, 50 \%$ 70\% тр.н.р. $-33.7 \%, 70 \%-90 \%$ тр.н.р. -35.8 , над 90\% тр.н.р. $-25.1 \%$.

За наличие или отсъствие на неравенства в рамките на посочената социална категория и нейните субкатегории, са използвани следните здравни, социални и икономически показатели.

Възрастта е един от най-силно диференциращите фактори, оказващи сериозно влияние върху развитието на дегенеративни и болестни процеси в човешкия организъм. Резултатите показват експоненциално нарастване на относителния дял на лицата с увреждания с повишаване на възрастта (Таблица 1). Почти две трети от изследваните лица с над $90 \%$ тр.н.р. и с над $70 \%$ до 90\% тр.н.р., са на 65 и повече години.

Полът, в качеството си на биологичен фактор, показва значително по-слаба връзка с разпределението на тежестта на уврежданията (Таблица 1). Разликата в относителните дялове между мъжете и жените при различните субкатегории се движи от 8,4 процентни пункта при лицата с над $90 \%$ тр.н.р. до 32,2 процентни пункта при лицата с над 70\% до 90\% тр.н.р.

Местоживеенето разкрива, че най-висок е относителният дял на лицата с увреждания в селата. Над една трета от лицата с най-висока степен на увреждане живеят в селата. Най-нисък е този относителен дял при столичани (Таблица 1). Подобно разпределение съответства на възрастовата специфика на населението в страната в различните по големина населени места.

Представените до тук фактори разкриват преди всичко различията в степента на настьпилите увреждания при респондентите. От гледна точка на проблемите на неравенствата

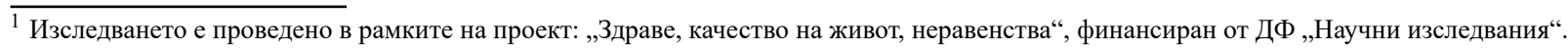


в здравето особен интерес представляват други четири фактора: образователен статус, чист доход на лице от домакинството, възможност за справяне с разходите за здраве и депривация в достьпа до здравни услуги (Таблица 1). Резултатите говорят за сравнително равномерно разпределение на относителните дялове на изследваните лица с различна образователна степен в отделните субкатегории на лица с увреждане. Тази равномерност е леко нарушена при респондентите с висше образование, където тя носи вълнообразен характер с пикове при лицата с над 70\% до 90\% тр.н.р. и лицата с до 50\% тр.н.р. В същите тези две субкатегории са концентрирани обаче и по-големите относителни дялове на лицата на 65 и повече години. Това подсказва синергизма на влияние на възрастовите проблеми, ако бъдат разглеждани от гледна точка на образователния статус. Очаквано вътре в субкатегориите на лицата с най-тежки увреждания найвисок е относителния дял на лицата с основно и по-ниско образование. Вероятно в случая се наслагва и влиянието на възрастовия фактор. Изненадващ обаче е фактът на равномерно разпределение на степента на увреждане и загубена работоспособност при лицата със средно образование.

Броят на членовете в домакинството оказва съществено влияние предимно върху емоционалната и физическата подкрепа на хората с увреждания от страна на значимите близки и върху размера на разполагаемия чист доход на член от домакинството. В случая не се наблюдава сериозно разделение между различните субкатегории лица с увреждания (Таблица 1). Притеснява обаче, високата концентрация на едночленни и двучленни домакинства и в четирите субкатегории - от малко под две трети до почти три четвърти. А това е сериозна предпоставка за живот в самота и изпълнен с множество лишения и трудности (Таблица 1).

Трудовият статус недвусмислено показва, че пенсионерите са основната субкатегория хора с висока степен на увреждане. Техният относителен дял в двете субкатегории с най-висока степен на увреждане е с около една трета повисок от относителния дял на интервюираните лица на 65 и повече години.

Средномесечният чист доход на член от домакинството показва някои ососбености. И при четирите изследвани субкатегории лица с увреждания се установява полярно натрупване в най-нискодоходните (до 200 лв. и от над 200 до 400 лв.) групи. Тук са съсредоточени с почти равен относителен дял над $80 \%$ от респондентите. В групата на лицата с чист месечен доход над 600 лв. и при субкатегориите на лицата с най-тежките степени на увреждания, този относителен дял заема мизерните 4,5\%-5\%. При другите две субкатегории лица с увреждания с чист среден месечен доход над 600 лв. е всяко 10-о лице (Таблица 1).

Естествен и очакван израз на ниското ниво на дохода на член от домакинството е депривацията в достъпа до здравни услуги. При всички субкатегории най-ярко е изразено наличието на финансови ограничения за заплащане на разходите за здраве. На второ и трето място, с близки относителни дялове, следва наличието на финансови затруднения при закупуване на лекарства и/или молбата за предписване на поевтини лекарства. Интересна особеност при този показател е фактьт, че и при двете посочени позиции относителният дял на лицата с под 50\% тр.н.р. е най-висок в сравнение с останалите респонденти. Общо финансовите ограничения в достъпа до здравни услуги са съдба на над половината до почти и повече от две трети от интервюираните лица (Таблица 1).

Налице е натрупване на относителните дялове в отрицателния полюс - „трудно“ и „много трудно“ при оценката на възможността за справяне с разходите за здраве. Разликите между „трудно“" и „лесно“ са в рамките на 5 до 8 пъти при различните субкатегории лица с увреждания. Ус- тановяват се сериозни различия в относителните дялове на респондентите с над $90 \%$ тр.н.р. в сравнение с останалите три субкатегории лица с увреждания. Впечатляващи са разликите по отношение на „много трудно“ и „трудно“ справяне с разходите между лицата с най-тежката степен на увреждане (49.2\%) и тези с най-лека степен на увреждане (65.4\%). Подобна обратна връзка, поради сравнително малкия брой интервюирани лица, тук не може да бъде обяснена. Самият факт на нейното съществуване изисква по-задълбочени изследвания.

Таблица 1. Социално-икономически показатели

\begin{tabular}{|c|c|c|c|c|}
\hline \multirow[t]{2}{*}{ Показатели } & \multicolumn{4}{|c|}{$\begin{array}{c}\text { Процент трайно намалена } \\
\text { работоспособност }\end{array}$} \\
\hline & над 90\% & 70\%-90\% & $50 \%-70 \%$ & под 50\% \\
\hline $\begin{array}{ll}\text { мъж } & \text { Пол } \\
\text { жена } & \end{array}$ & $\begin{array}{l}45.8 \\
54.2\end{array}$ & $\begin{array}{l}33.9 \\
66.1\end{array}$ & $\begin{array}{l}35.4 \\
64.6\end{array}$ & $\begin{array}{l}42.3 \\
57.7\end{array}$ \\
\hline $\begin{array}{l}\quad \text { Възраст } \\
\text { до } 24 \text { г. } \\
25-44 \text { г. } \\
45-64 \text { г. } \\
65+\text { г. }\end{array}$ & $\begin{array}{r}1.7 \\
6.7 \\
30.0 \\
61.6\end{array}$ & $\begin{array}{r}2.3 \\
2.3 \\
29.9 \\
65.5\end{array}$ & $\begin{array}{l}- \\
12.4 \\
44.1 \\
43.5\end{array}$ & $\begin{array}{l}19.2 \\
23.1 \\
57.7\end{array}$ \\
\hline $\begin{array}{l}\text { София Местоживеене } \\
\text { областен град } \\
\text { град } \\
\text { село }\end{array}$ & $\begin{array}{l}13.3 \\
30.0 \\
17.5 \\
39.2\end{array}$ & $\begin{array}{l}11.1 \\
38.0 \\
17.6 \\
33.3\end{array}$ & $\begin{array}{l}18.6 \\
24.2 \\
28.0 \\
29.2\end{array}$ & $\begin{array}{l}26.9 \\
23.1 \\
15.4 \\
34.6\end{array}$ \\
\hline $\begin{array}{l}\text { Брой членове на домакинството } \\
\text { едночленно } \\
\text { двучленно } \\
\text { тричленни } \\
4 \text { и повече члена }\end{array}$ & $\begin{array}{l}22.7 \\
43.7 \\
14.3 \\
19.3\end{array}$ & $\begin{array}{l}25.3 \\
45.9 \\
12.4 \\
16.5\end{array}$ & $\begin{array}{l}25.6 \\
36.3 \\
21.9 \\
16.3\end{array}$ & $\begin{array}{r}34.6 \\
38.5 \\
7.7 \\
19.2\end{array}$ \\
\hline $\begin{array}{l}\text { Образование } \\
\text { висше } \\
\text { средно } \\
\text { основно } \\
\text { по-ниско от основно и } \\
\text { без образование }\end{array}$ & $\begin{array}{r}15.3 \\
53.4 \\
27.1 \\
4.2\end{array}$ & $\begin{array}{l}18.1 \\
51.6 \\
21.6\end{array}$ & $\begin{array}{r}14.9 \\
55.9 \\
21.1 \\
\\
8.0\end{array}$ & $\begin{array}{l}23.1 \\
53.8 \\
23.1\end{array}$ \\
\hline $\begin{array}{l}\quad \text { Трудов статус } \\
\text { работещ } \\
\text { безработен } \\
\text { пенсионер } \\
\text { учащ } \\
\text { друго }\end{array}$ & $\begin{array}{r}2.5 \\
1.7 \\
93.3 \\
- \\
2.5\end{array}$ & $\begin{array}{r}5.8 \\
1.8 \\
87.1 \\
1.8 \\
3.5\end{array}$ & $\begin{array}{r}18.0 \\
3.1 \\
75.8 \\
- \\
3.1\end{array}$ & $\begin{array}{r}15.4 \\
11.5 \\
73.1 \\
- \\
-\end{array}$ \\
\hline $\begin{array}{l}\text { Чист доход на лице от } \\
\text { домакинството } \\
\text { до } 200 \text { лв. } \\
200-400 \text { лв. } \\
400-600 \text { лв. } \\
\text { над } 600 \text { лв }\end{array}$ & $\begin{array}{r}32.1 \\
50.9 \\
12.5 \\
4.5\end{array}$ & $\begin{array}{r}34.0 \\
49.7 \\
11.3 \\
5.0\end{array}$ & $\begin{array}{l}34.3 \\
44.3 \\
11.4 \\
10.0\end{array}$ & $\begin{array}{r}33.3 \\
47.6 \\
9.5 \\
9.6\end{array}$ \\
\hline $\begin{array}{l}\text { Депривация в достьпа до } \\
\text { здравни услуги } \\
\text { наличие на финансови ограниче- } \\
\text { ния при закупуване на } \\
\text { лекарства } \\
\text { наличие на финансови ограниче- } \\
\text { ния за заплащане на разходите } \\
\text { за здраве } \\
\text { молба за предписване на } \\
\text { по-евтини лекарства }\end{array}$ & 37.5 & 31.0 & 36.6 & 50.0 \\
\hline $\begin{array}{l}\text { Възможност за справяне с } \\
\quad \text { разходите за здраве } \\
\text { много лесно и лесно } \\
\text { много трудно и трудно }\end{array}$ & $\begin{array}{l}10.2 \\
49.2\end{array}$ & $\begin{array}{r}6.4 \\
69.6\end{array}$ & $\begin{array}{r}8.1 \\
65.8\end{array}$ & $\begin{array}{l}11.5 \\
65.4\end{array}$ \\
\hline
\end{tabular}

Следващата група показатели включват обективно установени от лекар заболявания, както от гл.т. на тяхната честота, така и от броя на заболяванията, установени от лекар при всеки един от респондентите. Освен това, като 
обективен показател за здравния статус, се приема и индекса на телесната маса (ИТМ) (Таблица 2). Относителният дял на най-често срещаните заболявания, установени от лекар, варира в доста широки граници. Водещо място и значение има хипертонията, която е установена при почти две трети от респондентите. Не по-малко е значението и на исхемичната болест на сърцето, която е диагностицирана при една трета от лицата с увреждания. Третото място по честота на установените диагнози са артрозите, което не изненадва в контекста на възрастовата структура на изследваната популация. На фона на непрекъснато увеличаващата се заболяемост от диабет в глобален мащаб, резултатите сочат, че всеки четвърти $(26.8 \%)$ от изследваните лица е с диагностициран диабет (Таблица 2).

Не по-малка значимост за повишаващия се брой на лицата с увреждания имат и ревматологичните заболявания $(22.6 \%)$, които сами по себе си показват застрашителното нарастване на автоимунните заболявания с различен характер и локализация. Резултатите от изследването ясно сочат значимостта на клас IX ,Болести на органите на кръвообращението“ от МКБ-10 във формирането на структурата на субкатегориите лица с увреждания. Това ясно кореспондира с нивото на смъртността от този клас болести в световен мащаб и по-специално у нас.

Таблица 2. Обективно установени здравни показатели

\begin{tabular}{|c|c|c|c|c|}
\hline Показатели & \multicolumn{4}{|c|}{ Относителен дял } \\
\hline $\begin{array}{l}\text { Най-често срещани заболявания, } \\
\quad \text { установени от лекар } \\
\text { хипертония } \\
\text { исхемична болест на сърцето } \\
\text { артрози } \\
\text { диабет } \\
\text { ревматологични заболявания } \\
\text { проводни нарушения на сърцето } \\
\text { остеопороза } \\
\text { гастрит, язва } \\
\text { сърдечна недостатъчност }\end{array}$ & \multicolumn{4}{|c|}{$\begin{array}{l}62.3 \\
33.8 \\
28.7 \\
26.8 \\
22.6 \\
19.3 \\
17.2 \\
15.9 \\
15.3\end{array}$} \\
\hline \multirow[t]{2}{*}{ Показатели } & \multicolumn{4}{|c|}{$\begin{array}{c}\text { Процент трайно намалена } \\
\text { работоспособност }\end{array}$} \\
\hline & над 90\% & 70\%-90\% & 50\%-70\% & под 50\% \\
\hline $\begin{array}{l}\text { Брой заболявания, установени } \\
\text { от лекар } \\
\text { нито едно } \\
\text { едно заболяване } \\
\text { две заболявания } \\
\text { три заболявания } \\
\text { четири и повече заболявания }\end{array}$ & $\begin{array}{r}6.7 \\
16.7 \\
13.3 \\
25.0 \\
38.3\end{array}$ & $\begin{array}{r}1.8 \\
15.2 \\
12.3 \\
25.7 \\
45.0\end{array}$ & $\begin{array}{r}4.4 \\
18.1 \\
15.0 \\
26.9 \\
35.6\end{array}$ & $\begin{array}{r}7.7 \\
7.7 \\
30.8 \\
26.9 \\
26.9\end{array}$ \\
\hline $\begin{array}{l}\text { Индекс на телесната маса } \\
\text { поднормално тегло } \\
\text { нормално тегло } \\
\text { наднормено тегло } \\
\text { затльстяване }\end{array}$ & $\begin{array}{r}2.5 \\
37.8 \\
28.6 \\
31.1\end{array}$ & $\begin{array}{r}1.8 \\
31.6 \\
38.6 \\
28.1\end{array}$ & $\begin{array}{r}1.9 \\
26.4 \\
38.4 \\
33.3\end{array}$ & $\begin{array}{r}4.0 \\
44.0 \\
40.0 \\
12.0\end{array}$ \\
\hline
\end{tabular}

Резултатите сочат нарастване на броя на заболяванията във всяка една субкатегория лица с увреждания. На този етап на изследването може само да се отбележи, че нито едно заболяване от тези, които са посочени при изследването, не са установени в най-висока степен при лицата с над $90 \%$ тр.н.р. и при лицата под 50\% тр.н.р. Най-високи са относителните дялове и при четирите субкатегории лица с увреждания с 4 и повече заболявания. При 3 и повече заболявания относителните дялове са почти идентични (Таблица 2).

Приема се, че ИТМ е един от най-важните показатели за здравния статус както по отношение на неговото настоящо състояние, така и по отношение на перспективите за влошаването му. С особено висока степен на риск за развитие на различни по вид и тежест заболявания, най-вече на болести на органите на кръвообращението, диабета и артрозите, се оценява наличието на затлъстяване както в резултат на нарушения на метаболизма, така и като последица от неправилен хранителен режим и ниска физическа активност. Резултатите показват, че при лицата с над 90\% тр.н.р и при лицата с над $50 \%$ до 70\% тр.н.р. една трета от респондентите са със затлъстяване. Показателно е, че проблемът и здравният риск от затлъстяването е най-нисък при лицата с до 50\% тр.н.р. Необходимо е да се отбележи наличието на висок относителен дял на лицата с наднормено тегло и сред четирите субкатегории лица с увреждания (Таблица 2).

Обективните показатели за оценка на здравето несъмнено дават своето отражение върху субективното оценяване на здравния статус и наличието или отсъствието на здравни проблеми. От гледна точка на специфичната проблематика, разглеждана в настоящата статия, както и от гледна точка на възможните ограничения в ежедневния живот, като следствие на тези здравни проблеми, визираните ограничения в значителна степен биха могли да повлияят и върху преминаването от една субкатегория в друга, по-тежка (Таблица 3).

Таблица 3. Субективно оценявани здравни показатели

\begin{tabular}{|c|c|c|c|c|}
\hline \multirow[t]{2}{*}{ Показатели } & \multicolumn{4}{|c|}{$\begin{array}{c}\text { Процент трайно намалена } \\
\text { работоспособност }\end{array}$} \\
\hline & над 90\% & 70\%-90\% & $50 \%-70 \%$ & под 50\% \\
\hline $\begin{array}{l}\text { Самооценка на здравето } \\
\text { добро и много добро } \\
\text { лошо и много лошо }\end{array}$ & $\begin{array}{l}10.8 \\
77.5\end{array}$ & $\begin{array}{l}10.7 \\
64.2\end{array}$ & $\begin{array}{r}9.4 \\
58.8\end{array}$ & $\begin{array}{l}26.9 \\
53.8\end{array}$ \\
\hline $\begin{array}{l}\quad \text { Брой здравни проблеми } \\
\text { нито един } \\
\text { един } \\
\text { два } \\
\text { три } \\
\text { четири и повече }\end{array}$ & $\begin{array}{r}5.8 \\
10.0 \\
14.2 \\
20.8 \\
49.2\end{array}$ & $\begin{array}{r}2.9 \\
8.8 \\
15.8 \\
18.1 \\
54.4\end{array}$ & $\begin{array}{r}1.8 \\
10.6 \\
20.5 \\
19.9 \\
47.2\end{array}$ & $\begin{array}{r}3.8 \\
11.5 \\
23.1 \\
26.9 \\
36.6\end{array}$ \\
\hline $\begin{array}{l}\text { Брой здравни проблеми, огра- } \\
\text { ничавали ежедневния живот } \\
\text { нито един } \\
\text { един проблем } \\
\text { два проблема } \\
\text { три проблема } \\
\text { четири и повече проблема }\end{array}$ & $\begin{array}{l}10.8 \\
20.0 \\
15.0 \\
20.8 \\
33.3\end{array}$ & $\begin{array}{r}9.4 \\
20.0 \\
22.4 \\
17.6 \\
30.6\end{array}$ & $\begin{array}{l}11.8 \\
18.0 \\
26.7 \\
16.8 \\
26.7\end{array}$ & $\begin{array}{r}3.8 \\
23.1 \\
30.8 \\
26.9 \\
35.4\end{array}$ \\
\hline Показатели & \multicolumn{4}{|c|}{ Относителен дял } \\
\hline $\begin{array}{l}\text { Най-често срещани здравни } \\
\text { проблеми, ограничавали } \\
\quad \text { ежедневния живот } \\
\text { сърдечносъдови проблеми } \\
\text { хипертония } \\
\text { болки в краката } \\
\text { болки в гърба (вкл. кръста) } \\
\text { болки в ръцете } \\
\text { дихателни проблеми } \\
\text { диабет }\end{array}$ & \multicolumn{4}{|c|}{$\begin{array}{l}49.5 \\
49.1 \\
45.5 \\
34.6 \\
20.8 \\
16.6 \\
15.3\end{array}$} \\
\hline
\end{tabular}

Самооиенката на здравето е един от най-често използваните способи за оценяване нивото на собственото здраве през последните повече от 20 години. Тя регистрира и динамиката на промените през определени периоди от време и сред различни социално-икономически групи, осигурява възможност за установяване на моментната картина на здравното самочувствие на изследваните лица. В тази връзка базата данни на СИЛК предоставя сериозни възможности.

Резултатите от изследването ясно сочат оценъчните възможности на интервюираните за самооценка на здравето. Проследява се категорично намаление на относителния дял на лицата, оценили здравето си като „лошо“ и „много лошо“ при всяка следваща по тежест субкатегория лица с увреждания. Разликата между субкатегориите с най-тежка и найлека степен на увреждания, дали такава оценка намалява от 
$77.5 \%$ на $53.8 \%$ или с 23.7 процентни пункта. И обратно, разликата между същите две субкатегории респонденти, оценили своето здраве като „добро“ или „много добро“, се увеличава с 16.1 процентни пункта.

Здравните проблеми, възникващи в резултат на обективния здравен статус при различните субкатегории лица с увреждания, води много често до наличието на по-широка палитра от здравни проблеми. При почти всички субкатегории лица с увреждания се установява наличие на повече от един здравен проблем. Особено сериозен е фактьт, че половината от изследваните лица с най-тежки степени на увреждане (над 70\% до 90\% тр.н.р и с над 90\% тр.н.р.) имат по 4 и повече здравни проблеми. Не стои много по-добре въпросът и при лицата в останалите две субкатегории (Таблица 3).

Здравните проблеми, сами по себе си, не биха имали такава висока аналитична стойност ако значителна част от тях не ограничаваше ежедневния живот (Таблица 3). Различията в относителните дялове при различните по брой проблеми, ограничаващи ежедневния живот и общия брой на здравните проблеми (става дума за 4 и повече проблеми), се движи в рамките от 15.9 процентни пункта при лицата с над 90\% тр.н.р. и при тези с над 50\% до 70\% тр.н.р. до 23.8 процентни пункта при лицата с над 70\% до 90\% тр.н.р. Най-ниска е тази разлика при лицата с под 50\% тр.н.р. (Таблица 3).

Очаквано, като най-широко разпространен здравен проблем, ограничаващ ежедневния живот, се манифестира болковия синдром в трите му разновидности (Таблица 3). Най-рискови обаче, в конкретния случай и според резултатите от изследването, са сърдечносъдовите проблеми и хипертонията, които засягат половината от респондентите. Не бива да се оставя без внимание фактьт, че други два проблема - дихателните проблеми и диабета, се отнасят до всяко шесто изследвано лице.

\section{Обсъжаане}

Наличието на значими различия, водещи в редица случаи и до изразени неравенства между различните социално-демографски субкатегории лица с увреждания доказва, че хората с увреждания не могат и не трябва да бъдат разглеждани като хомогенна, аморфна категория. Тези различия по отношение на пола, независимо от незначителния превес на жените в социалната категория „лица с увреждания“ $(52.1 \%)$, показва значителни отклонения от средния относителен дял в различните субкатегории. Най-силно изразена е тази разлика при субкатегорията над 70\% до 90\% тр.н.р. - в случая относителният дял на жените е почти два пъти по-висок от този на мъжете. В най-тежката степен на увреждане - над 90\% тр.н.р., разликата обаче, е само 8.4 процентни пункта в полза на жените. Разликата при най-леката субкатегория - под 50\% тр.н.р., също не е особено голяма 15.4 процентни пункта. Това дава основание да се приеме, че от гледна точка на половите различия, при жените те определено са по-ярко изразени при всички субкатегории и по-специално при лицата с над 50\% тр.н.p. до 70\% тр.н.р. и лицата с над $70 \%$ тр.н.р. до $90 \%$ тр.н.р. В случая би трябвало да се вникне по-дълбоко в очерталия се проблем при съвместни изследвания на екип от различни специалисти.

Възрастовите различия показват, че при младите възрастови групи (до 24 г. и 25-44 г.) относителният дял на лицата с увреждания е минимален. При двете най-леки по степен на увреждане субкатегории те или изобщо не се наблюдават (при лицата до 24 години), или са рядко срещани (при лицата на 25-44 г.). Този факт дава основание да се изведе на преден план първичната и вторичната профилактика и рехабилитация, с оглед снижаване на риска от поява и развитие на по-тежки форми на увреждания. Относителният дял на лицата с увреждания скокообразно нараства при възрастовата група 45-64 години. Техният относителен дял в социалната категория „лица с увреждания“ заема малко повече от една трета (34.3\%) от изследваната популация. Екстремното нарастване на лицата на 65 и повече години в най-тежките по степен на увреждане субкатегории, говори за увеличаване значимостта на дегенеративните промени в процесите на стареене.

Местоживеенето само по себе си у нас е натоварено със сериозен риск по отношение на неравенствата в здравето. От една страна това е свързано с образователната структура на населението в различните типове населени места. От друга страна, в демографската структура на малките населени места преобладава населението в предпенсионна и пенсионна възраст. В същото време всеизвестни са неравенствата в качеството на живот между големите и малките населени места от гледна точка на инфраструктурата в двете, включително и в наличието и достъпността на здравните услуги. Половината от лицата с най-тежките форми на увреждане живеят в малките градове, а в селата този относителен дял е $65 \%$. Съвместното, синергично действие на редица социални ограничители, включително образованието и възрастта, представлява основата на социално-икономическата съставяща на неравенствата в здравето при лицата с увреждания.

Интересна зависимост се установява при анализа на връзката между тежестта на уврежданията ${ }^{2}$ и чистия средномесечен доход на лице от домакинство. При субкатегориите с тежки увреждания и при различните подоходни групи почти две трети от респондентите в изследваната популация имат доход до 600 лв. С около 20 процентни пункта по-малко са респондентите с доход над 600 лв. Същевременно с малко повече от една трета е по-нисък относителният дял на лицата с по-леки степени на увреждане с доход до 600 лв. С доход над 600 лв. са малко повече от половината респонденти от групата на лицата с по-леки уреждания. Или, ако при нискодоходните групи разликите в личния доход между лицата с тежки увреждания и тези с по-леки увреждания, е около 30-35 процентни пункта, то при най-високодоходната група (над 600 лв.), тази разлика е само 10.4 процентни пункта. С други думи, колкото по-тежки са уврежданията, толкова помалък е относителният дял на респондентите с доход над 600 лв. И обратното, колкото по-леки са уврежданията, толкова по-голям е относителният дял на лицата с доход над 600 лв $^{3}$

Казаното до тук показва наличието на значително поголям резерв трудоспособност при по-леките степени увреждане. Не бива да се изпуска от внимание още една важна особеност на повдигнатите проблеми за съществен резерв от налична трудоспособност при по-леките степени на увреждане. При тях две трети от респондентите са на възраст от 25 до 44 години. Същевременно при всички разработени до момента стратегии за демографско развитие въпросът за значителния резерв от трудови възможности при по-леките степени на увреждане не е поставян.

Анализираните досега проблеми дават основание да се говори за депривация в достыпа до здравни услуги в резултат на влиянието както на социално-икономически, така и на здравно-организационни и нормативни бариери/фактори. Депривацията в сферата на здравеопазването може да бъде разглеждана като резултат от възможностите за достъп до здравни услуги. Под достьп до здравни услуги се разбира нормативно приетите принципи и правила както в Консти-

\footnotetext{
2 За целите на анализа условно разделяме 4-те субкатегории лица с увреждания на две групи: лица с тежки увреждания (над $90 \%$ и над $70 \%$ до $90 \%$ тр.н.р.) и с по-леки увреждания - всички лица с до $70 \%$ тр.н.р.

${ }^{3}$ Необходимо е да се отчита фактьт, че в тази подоходна група са попаднали само 7\% от изследваните лица.
} 
туцията на страната, така и в пакета от закони, регулиращи системата на здравеопазването. Този достъп може да бъде възпрепятстван или сведен до нула при положение на липса на достьпност до здравни услуги. Под достьпност се разбира съществуването на социалноикономически, административни и организационни условия, съдействащи реализирането на нормативно установения достъп. Всяка социална бариера, независимо от нейния характер, нарушава, ограничава или заличава достъпността до здравни услуги.

Причините за депривацията (самоограничението) по отношение на реализиране на достъпа до здравни услуги могат да имат най-различен характер: поведенчески, образователни, икономически (финансови), културно-битови, религиозни, пространствени, свързани с традициите и обичаите и др. Независимо от това, какви са причините, нарушението на достъпността до здравни услуги много често води до влошаване на здравния статус и до хронифициране на заболяванията с всички произтичащи от това последици, включително и до задълбочаване на социалните неравенства в здравето.

От комплекса въпроси, свързани с депривацията в достьпа до здравни услуги особено място заема възможността на лицата и домакинствата да се справят с обективно необходимите разходи за здраве. Неравенството в това отношение особено добре проличава при съпоставяне на отговорите за тези възможности, дадени от двете досега разглеждани групи - лица с тежки и лица с по-леки увреждания. Почти две трети от хората с тежки увреждания (62.2\%) заявяват, че „много трудно“и „трудно“ се справят с разходите за здраве. При лицата с по-леки увреждани този относителен дял е 1.6 пъти по-мальк (37.8\%). Независимо, че лицата с увреждания, справящи се „лесно“ и „много лесно“ представляват едва $8.2 \%, 59 \%$ от тях са с тежки увреждания, а $41 \%$ - с по-леки. Ясно личат разликите в относителните дялове между двете полярни групи: с тежки и с по-леки увреждания. При справящите се „много трудно“ и „трудно“ разликата между лицата с тежки и лицата с по-леки увреждания е 24.4 процентни пункта, а при тези, които заявяват, че се справят „много лесно“ и ,лесно“, тя е 18 процентни пункта. Това показва, че при по-тежките степени на увреждане справянето с разходите за здраве, независимо от по-високите нива̀ на подкрепа, е много по-трудно.

Като последица от ясно изразените затруднения при справяне с разходите за здраве, стои въпросът за реално осъществените самоограничения на лицата и домакинствата в разходите за здраве. Налице е един твърде тревожен факт, показващ, че преобладаващата част от лицата с тежки увреждания $(57.6 \%)$ се е наложило да правят ограничения, докато при лицата с по-леки степени на увреждане този относителен дял е $42.4 \%$, т.е. има разлика от 15 процентни пункта. Това показва, че лицата с тежки форми на увреждане, в резултат на цялостната си социалноикономическа и здравна ситуация, по същество изпадат в ситуация на дискриминация. Причините за това могат да се търсят в неадекватните и непълни здравни и социални политики.

\section{Заключение}

Отсъствието на официална статистическа информация за здравните и социално-икономическите проблеми във вътрешната структура на категорията „лица с увреждания“ у нас ограничава възможностите за проследяване на динамиката, процесите и съотношенията между отделните субкатегории. От друга страна фактьт, че няма единна структура на социалната категория ,лица с увреждания“, разработена и приета от Евростат, свежда до нула каквито и да е опити за сравнителни изследвания между страните. Подобен подход силно затруднява опитите за сравнение на ефективността и ефикасността на съществуващите в отделните страни политики, както и приложимостта им в конкретните социално-икономически условия във всяка друга страна.

От съществено значение е и сравнително честата промяна на критериите за определяне от ТЕЛК на отделните субкатегории, което само по себе си е свързано с размера на финансовата подкрепа, получавана от лицата с увреждания. Дълбоко погрешна е и практиката почти всичко да се свежда до тази финансова подкрепа, докато останалите сериозни фактори за успешна интеграция на лицата с увреждания избягват от вниманието на политиците. Напълно са загърбени и въпросите, свързани със спецификата на трите основни потока клиенти на социалната политика в сферата на уврежданията. Налице са три големи групи, всяка от които се нуждае от специфична социална подкрепа и обгрижване. Универсалният и унифициран подход отдавна доказа своята несъстоятелност.

Тези три потока на клиенти на социалната политика в сферата на интеграцията на хората с увреждания се характеризират по следния начин. Първият поток се формира от лица, които се нуждаят от помощта на социалните институции след като са били или и в момента са активни участници в сферата на труда, имат изградени трудови навици и нагласи и различна по вид и степен професионална подготовка и квалификация. В този случай би трябвало да се говори и изгражда система за реинтеграция, съответстваща на съхранената трудоспособност и удължаване на активния трудов живот. Това само по себе си би могло да се разглежда и използва като социален механизъм за съхранение и евентуално развитие на остатъчния социален капитал в не малка част от лицата с увреждане, особено при тези с по-лека степен на увреждане. С подобен подход би могло, като страничен ефект, да се подпомогнат нарастващите нужди на пазара на труда от кадри с различна степен на квалификация.

При сегашния подход лицата от субкатегорията с найтежка степен на увреждане априори са изключени от възможността за съхранение на техния социален капитал. Само по себе си това представлява недопустимо етикетиране и изолация от най-висшата човешка дейност - труда.

Вторият поток от клиенти на социалните институции се формира от лица с тежки вродени увреждания, които остро се нуждаят от първична социална интеграция. Ясно е, че социалните политики за този поток категорично трябва да се различават от политиките, необходими при първия поток. Характерьт и степента на уврежданията в този случай изисква преди всичко хуманитарна ориентация, стремяща се да тушира социално-психологическите последици от наличните дефицити, да разшири възможностите за образование и професионална квалификация.

Третият поток от клиенти на социалните институции се формира от лицата в трудоспособна възраст, за които приоритет са потребностите от комплексна рехабилитация (медицинска, професионална/трудова, социална и психологическа).

Възрастовата специфика подсказва, че причисляването на различните по вид и тежест увреждания в резултат на естествените процеси на стареене на организма би трябвало да се разграничава от уврежданията, настьпили в резултат на морфологични промени, свързани с различни по вид и тежест болестни процеси и травматични увреждания. Подобно разграничаване би улеснило разработването и внедряването на специфични и индивидуализирани социални политики, свързани с различията в генезата на процесите на увреждане и техните социални последици.

Размерът на чистия средномесечен доход на лицата с увреждания и техните домакинства подсказва, че депривацията, в т.ч. и на разходите за здраве, е основна жизнена 
стратегия за голяма част от представителите на тази социална категория. Това неминуемо води до изпадане и трайно съществуване в условията на относителна, дори и абсолютна бедност, а от тук и до влошаване на качеството на живот и до увеличаване и трайно съществуване на големи социални неравенства, в т.ч. и неравенства в здравето.
Съществен принос при един диференциран подход би могъл да се очаква от замяната на съществуващия административно-благотворителен модел на уврежданията с биопсихологосоциалния модел на уврежданията, без да се приоретизира който и да е елемент на модела за сметка на другите.

$$
* *
$$

ЕВРОПЕЙСКАТА КОНЦЕПЦИЯ ,КОМПЛЕМЕНТАРНА И АЛТЕРНАТИВНА МЕДИЦИНА“ - ИСТОРИЯ, СЬЩНОСТ И МЯСТО В ОБЩЕСТВЕНОТО ЗДРАВЕОПАЗВАНЕ

\author{
И. Капинчева, Д. Ванкова
}

\title{
PAN-EUROPEAN CONCEPT „COMPLEMENTARY AND ALTERNATIVE MEDICINE" - HISTORY, CONTENT AND PUBLIC HEALTH IMPORTANCE \\ I. Kapincheva, D. Vankova
}

\begin{abstract}
Рез юм е. Световната здравна организация (СЗО) подкрепя от десетилетия включването на "допълвашите и алтернативни терапевтични практики” в здравните системи. За да се постигне това, СЗО очертава терапевтичната територия: “традиционна и комплементарна медицин” (ТКМ). По късно, Европейският съюз (ЕС) създава концепцията: „, комплементарна и алтернативна медицина“ (КАМ), която отразява лечебните и културните традици на държавите от европейския континент. Главна иел на настоящата статия е да се дефинира и представи европейската концепџия КАМ, и нейното място в общественото здравеопазване. Приема се, че термините „, неконвенционална медицина “, „КАМ“ и „ТКМ“ са синоними и са взаимозаменяеми. Очертани са КАМ подходите, които са в основата на всички видове КАМ терапии. Включени са следните терапевтични методи: акупунктура; антропософска медииина; аюрведа; йога; кинезиология (Kinesiology); натуропатия (Naturopathic or Traditional European Medicine); остеопатия; рефлексотерапия (Reflexology); тибетска медицина; фитотерапия (herbal medicine); хиропрактика (Chiropractic); хомеопатия; ииаиу (Shiatsu). В заключение, независимо от нарастващата популярност, използването на КАМ-методите в Европа не е добре проучено. КАМ е иновативна територия, разчитащза на терапевтични традиции и богат емпиричен опит, но сравнително малко изследвана. Научните изследвания, свързани с КАМ-подходите и проучванията върху ефективността, ефикасността и безопасността на КАМ-методите са навременни и необходими.
\end{abstract}

S u $\boldsymbol{m}$ m a ry. The World Health Organization (WHO) has been supporting for decades the integration of "complementary and alternative therapeutic practices" in healthcare systems. To achieve this, the WHO-concept of "traditional and complementary medicine" (TCM) has emerged. In response to these global trends, the European Union (EU) has created the concept of "complementary and alternative medicine" (CAM), which reflects the healing and cultural traditions of the EU member states. The main purpose of this article is to define and present the European concept of CAM and its place in public healthcare. The terms "unconventional medicine", "CAM", "TCM" are synonymous and are used interchangeably. Further, the universal CAM-approaches are outlined. The following therapeutic methods are included in KAM: acupuncture; anthroposophic medicine; ayurveda; yoga; kinesiology; naturopathic or traditional European medicine, osteopathy, reflexology, Tibetan medicine, phytotherapy, chiropractic, homeopathy, Shiatsu. The conclusion is, CAM is an innovative territory relying on therapeutic traditions and requiring theoretical and empirical research, related to effectiveness, efficiency and safety of CAM-methods and medicines.

Key words: „Complementary and Alternative Medicine” (CAM), Europe

\section{Въведение}

Световната здравна организация (С3О) подкрепя от десетилетия включването на „допълващите и алтернативни терапевтични практики" в здравните системи. За да се постигне това, СЗО очертава терапевтичната територия: „,традиционна и комплементарна медицина” (ТКМ), включваща в себе си лечебни методи, които не са характерни за западната медицина. СЗО създава глобалната Стратегия за развитие на традиционната медицина (Traditional Medicine Strategy 2014-2023) [1].

В лекцията си на Международната конференция по ТКМ (Делхи, Индия, 2013 г.) д-р Маргарет Чан, тогава генерален директор на СЗО, аргументира мястото на ТКМ-подходите като важен компонент на здравните системи. Според нея потребителите на здравни услуги в световен мащаб проявяват все по-голям интерес към ТКМ, поради което последната играе важна роля в икономическото развитие на някои страни, като намалява разходите за здравето. Освен това в научните изследвания в ТКМ-областта е постигнат голям напредък. Въз основа на тези факти, С3О подкрепя по-задълбочена интеграция на ТКМ в здравните системи, като за целта регулаторните агенции, потребителите и осигуряващите здравни услуги трябва да обсъдят как може да бъде постигнато това интегриране [1]. В отговор на тези световни тенденции в общественото здравеопазване, Европейският съюз (ЕС) създава концепцията за „комплементарна и алтернативна медицина“(КАМ), която отразява лечебните и културните традиции на държавите от европейския континент.

Главна цел на настоящата статия е да се представи Европейската концепция за КАМ и нейното място в общественото здравеопазване. Дефинира се КАМ като понятие. Очертават се КАМ-подходите и видовете КАМ-терапии. Доказва се нуждата от научни изследвания в тази посока, за да се аргументира мястото на КАМ в общественото здравеопазване. 